\title{
Wyzwania dla państwa prawa i gospodarki w dobie pandemii
}

Naczelną zasadą ustrojową determinującą system prawa jest zasada demokratycznego państwa prawnego wyrażona w art. 2 Konstytucji Rzeczypospolitej Polskiej ${ }^{1}$. Pierwszym jej wyznacznikiem jest zasada praworządności opisana w art. 7 Konstytucji RP, ukazująca normatywną powinność organów władzy publicznej do działania na podstawie i w granicach prawa. Drugim zaś zasada proporcjonalności ujęta w art. 31 ust. 3 Konstytucji RP, ograniczająca ingerencję władzy publicznej w sferę praw jednostki. Przeciwważenie tych zasad ma istotne znaczenie w procesie tworzenia i stosowania prawa. W paradygmacie naturalistycznym prawoznawstwa ${ }^{2}$ wskazuje się na instrumentalny charakter prawa jako zespołu dyrektyw racjonalnego sterowania procesami społecznymi ${ }^{3}$. Wizja ta oparta jest na założeniu, że ,prawo oderwane od materialnego kontekstu, od faktów (w tym również od faktów ekonomicznych) staje się abstrakcyjnym systemem obowiązujących norm"4. W takim ujęciu prawo nie może ignorować zjawisk, jakie zachodzą w szeroko pojętej rzeczywistości społecznej. Zagadnienie to wydaje się być szczególnie istotne w dobie kryzysu gospodarczego, wywołanego pandemią koronawirusa SARS-CoV-2.

Artykuły zebrane w 37 tomie czasopisma „Studenckie Prace Prawnicze, Administratywistyczne i Ekonomiczne" zatytułowanym Wyzwania dla państwa prawa i gospodarki w dobie pandemii podejmują próbę oceny tego, czy tworzone normy prawne są efektywnym środkiem do osiągnięcia najwyżej preferowanych stanów

${ }^{1}$ Konstytucja Rzeczypospolitej Polskiej z dnia 2 kwietnia 1997 roku, Dz.U. z 1997 r. Nr 78, poz. 483 (dalej: Konstytucja RP).

2 Zob. J. Stelmach, Naturalistyczny i antynaturalistyczny model teorii prawa, „Studia Prawnicze" 1985, z. 3-4 (81-82).

${ }^{3}$ Por. L. Morawski, Główne problemy współczesnej filozofii prawa. Prawo w toku przemian, Warszawa 2005, s. 365.

4 J. Stelmach, B. Brożek, W. Załuski, Dziesięć wykładów o ekonomii prawa, Warszawa 2007, s. 23. 
rzeczy w aktualnej rzeczywistości społecznej. Niniejsze wydanie jest przeglądem analiz naukowych, w których autorzy — studenci, doktoranci, doktorzy — zaprezentowali spostrzeżenia na temat kierunków zmian polityki legislacyjnej i gospodarczej w Polsce. Dyskurs prowadzony jest w sposób dwutorowy — z jednej strony opracowanie to stawia prawne kryteria oceny wybranych regulacji, $z$ drugiej zaś odwołuje się do myśli ekonomicznej na temat modelu systemu gospodarczego.

Problematykę prawa konstytucyjnego podejmuje Piotr Soroka w artykule zatytułowanym Jakie sa skutki naruszenia zasady bezstronności i obiektywizmu w wypadku Trybunatu Konstytucyjnego? Przyczynek do dyskusji. W swojej pracy dokonał analizy zagadnienia wolności i praw obywatela na tle obecnego funkcjonowania Trybunału Konstytucyjnego.

W duchu filozofii prawa powstał artykuł autorstwa Mikołaja Bednarka zatytułowany Czy obecnie możliwa jest zmiana sposobu myślenia praktyki prawniczej? Recenzja ksiązki Wiadomość od cesarza Michała Stambulskiego (Scholar 2020). Inspiracją tego opracowania były dwa ujęcia nauki o prawie — analityczne i empiryczne, traktowane jako jej odrębne modele.

Do obszaru badawczego doktryn politycznych i prawnych należy artykuł autorstwa Bartosza Chrząszcza Bezkompromisowa ucieczka do dyktatury. Teologia polityczna Juana Donoso Cortésa. Autor opisał tu koncepcję dyktatury w imię ladu prawdziwego.

Prawa karnego dotyka opracowanie Michała Jerzego Dębowskiego zatytułowane Wykładnia językowa typizacji narażenia na zarażenie. W pracy tej autor wykorzystał tak zwane podejście tekstowe do odkodowania treści znamion typu czynu zabronionego opisanego w art. 161 k.k. W obszarze prawa karnego powstała także praca Jana Kluzy — Bład co do tożsamości pokrzywdzonego i zboczenie działania w prawie karnym. Autor dokonał w niej prawnokarnej oceny sposobu działania sprawcy popełniającego czyn zabroniony na szkodę innej osoby niż obejmowana jego zamiarem. Do norm prawa karnego odwołuje się także artykuł Agaty Ziobroń pod tytułem Deepfake a prawo karne. Uwagi de lege lata $i$ de lege ferenda dotyczace fatszywej pornografii. Została w nim poruszona tematyka wykorzystania techniki deep fake do produkcji fałszywej pornografii w kontekście przedmiotu ochrony przepisów typizujących przestępstwo zniesławienia określone w art. 212 k.k. i przestępstwo znieważenia wskazane w art. 216 k.k. Kontynuacją rozważań na temat praktyki postępowania wobec osób z zaburzeniami psychicznymi, stwarzających zagrożenie życia, zdrowia lub wolności seksualnej innych osób jest publikacja Patryka Kuklińskiego pod tytułem Praktyka funkcjonowania Krajowego Ośrodka Zapobiegania Zachowaniom Dyssocjalnym. Uwagi na tle wyroku Trybunatu Konstytucyjnego z 23 listopada 2016 roku w sprawie K 6/14 - czesść II.

Zagadnienie organizacji posiedzenia przygotowawczego wyłożył Mariusz Nowak w artykule Posiedzenia przygotowawcze w sprawach cywilnych przed sadem pierwszej instancji. Podobną tematykę porusza także artykuł Łukasza Chyli pod tytułem Uwagi odnośnie do reformy polskiego prawa arbitrażowego w zakresie 
sporów wewnątrzkorporacyjnych, który stanowi naukowe opracowanie instytucji zapisu na sąd polubowny dotyczące sporów ze stosunku spółki w rozumieniu art. 1163 w zw. z art. 1157 k.p.c.

Za problem badawczy nauki o prawie cywilnym należy uznać zagadnienie dotyczące umowy przekazania nieruchomości. Zakres jej dopuszczalnej analogii do umowy darowizny wyznaczył Bartłomiej Krupowicz w artykule zatytułowanym Uwagi na temat dopuszczalności analogicznego stosowania przepisów o darowiźnie do umowy przekazania nieruchomości.

Do gałęzi prawa administracyjnego można przyporządkować artykuł Macieja Szałęgi pod tytułem Problematyka ustalenia stron postępowania administracyjnego w sprawie wydania pozwolenia wodnoprawnego. W pracy tej autor poddał analizie konstrukcję prawną strony postępowania w sprawach dotyczących pozwoleń wodnoprawnych w rozumieniu art. 401 ust. 1 ustawy z dnia 20 lipca 2017 roku - Prawo wodne. W tematykę ustrojowego prawa administracyjnego wpisuje się tekst Pawła Bącala zatytułowany Status prawny młodzieżowych rad powiatów. W opracowaniu tym podjęto próbę zdefiniowania kategorii młodzieżowych rad powiatów oraz omówiono procedury ich powstawania.

Od niedawna w dyskursie naukowym jako nową gałąź prawa wyodrębnia się prawo medyczne. Jest to zespół norm regulujących sposób działania podmiotów leczniczych i innych podmiotów uczestniczących w procesie diagnozy i leczenia pacjentów.

W niniejszym wydaniu prezentujemy glosę aprobującą autorstwa Hanny Cichockiej do wyroku Trybunału Sprawiedliwości Unii Europejskiej z dnia 7 grudnia 2017 roku w sprawie C-329/16. W pracy tej autorka skomentowała orzeczenie w sprawie obowiązku certyfikacji oprogramowania monitorującego stan zdrowia pacjenta jako wyrobu medycznego.

Martin Pracný w opracowaniu Czechosłowacka reforma walutowa z 1945 roku przybliżył kierunki polityki monetarnej na obszarach byłej Czechosłowacji po II wojnie światowej.

Opisem nowych tendencji w obszarze marketingu zajęły się Justyna Młynarczyk i Joanna Parcheta w publikacji pod tytułem Wplyw zmian $w$ działaniach marketingowych firm na zachowania konsumentów w czasie pandemii COVID-19. Autorki rozważyły zagadnienie reklamy jako instrumentu oddziaływania na preferencje zakupowe konsumentów. Arleta Pakuła w artykule Marka pracodawcy i motywacja do pracy $w$ handlu detalicznym - w świetle badań ankietowych podjęła zaś próbę zdefiniowania pojęć marki i wizerunku pracodawcy oraz wskazała czynniki wpływające na zadowolenie z pracy.

W obszarze teorii ekonomii powstał artykuł Mateusza Borkowskiego zatytułowany Efektywność w ujęciu mikro- i makroekonomicznym w myśli ekonomicznej — przeglad teoretyczny. W pracy tej autor dokonał chronologicznego, syntetycznego uporządkowania osiągnięć myśli ekonomicznej w zakresie pojęcia efektywności ekonomicznej. 
Oddając w ręce czytelników najnowszy tom czasopisma, głęboko wierzymy, że podjęte $\mathrm{w}$ nim rozważania okażą się ważnym głosem w dyskusji na ważkie tematy $\mathrm{w}$ dziedzinie prawa i ekonomii oraz przyczynią się do dalszej refleksji naukowej w tych obszarach.

Rafat Kowalski

ORCID: 0000-0002-4707-5646

Uniwersytet Wrocławski 